\title{
Efek Pembelajaran Cooperative Tipe Jigsaw Berbantuan Lembar Kerja Siswa terhadap Hasil Belajar IPA Siswa SMP
}

\author{
Selvianus San ${ }^{1]}$, Emilianus Jehadus ${ }^{2]}$, Silfanus Jelatu ${ }^{3]}$ \\ Universitas Katolik Indonesia Santu Paulus Ruteng \\ E-mail: ${ }^{1]}$ hezosansel_24@yahoo.com \\ ${ }^{2]}$ rebasarong@gmail.com \\ ${ }^{3]}$ silfanusjelatu@yahoo.co.id
}

\begin{abstract}
Abstrak
Penelitian ini bertujuan untuk membuktikan pengaruh model pembelajaran kooperatif tipe jigsaw berbantuan lembar kerja siswa (LKS) terhadap hasil belajar siswa, secara khusus hasil belajar IPA. Penelitian ini merupakan penelitian eksperimen yang dilakukan di SMPN Lengor, Manggarai NTT. Desain penelitian ini adalah posttest only control group design. Populasi pada penelitian ini adalah seluruh siswa kelas VIII SMPN Lengor tahun ajaran 2018/2019 yang berjumlah 120 orang. Sebanyak 47 siswa yang tersebar di dua kelas terpilih sebagai kelompok sampel. Pemilihan sampel menggunakan teknik cluster sampling. dengan Hasil pemilihan tersebut diperoleh kelas VIIIA sebagai kelas eksperimen dan kelas VIIIC sebagai kelas kontrol. Instrumen penelitian yang digunakan adalah tes multiple choice dengan empat alternatif jawaban. Intrumen terlebih dahulu diuji tingkat validitas, reliabilitas, daya beda, dan taraf kesukaran. Data selanjutnya dianalisis dengan menggunakan uji t. Sebelum dilakukan uji hipotesis, terlebih dahulu dilakukan uji asumsi yakni normalitas dan homogenitas. Berdasarkan hasil penelitian diperoleh bahwa nilai rata-rata posttest kelas eksprimen adalah 80.5 dan kelas kontrol sebesar 59,6. Berdasarkan data hasil analisis diperoleh $t_{\text {hitung }}=9,49$ dan $t_{\text {tabel }}=1,68$ pada taraf signifikan $\alpha=0,05$. Karena $t_{\text {hitung }} \geq t_{\text {tabel }}$, maka $\mathrm{H}_{0}$ ditolak dan $\mathrm{H}_{1}$ diterima, yang artinya terdapat perbedaan hasil belajar IPA Biologi siswa antara penggunaan model pembelajaran kooperatif tipe jigsaw berbantuan lembar kerja siswa dengan model pembelajaran langsung. Selain itu, dapat pula disimpulkan bahwa model pembelajaran kooperatif tipe jigsaw berbantuan lembar kerja siswa (LKS) berpengaruh positif terhadap hasil belajar IPA Biologi siswa kelas VIII SMPN Lengor-Rahong Utara tahun ajaran 2018/2019.
\end{abstract}

Kata Kunci: Pembelajaran kooperatif, Jigsaw, Hasil belajar IPA.

\section{The Effect of Cooperative Learning Jigsaw Type with Student Worksheet towards Lerning Outcomes of Junior High School Students}

\begin{abstract}
This study aims to prove the influence of the jigsaw type cooperative learning model assisted by student worksheets (LKS) on student learning outcomes, precisely science learning outcomes. This research is experimental research conducted at Lengor Middle School, Manggarai, NTT. The design of this study was posttest only control group design. The population in this study was all eighth-grade students of Lengor Middle School in the 2018/2019 academic year, totaling 120 people. A total of 47 students
\end{abstract}


spread across two classes were selected as sample groups. The sample selection uses a cluster sampling technique. The results of the selection obtained class VIIIA as the experimental class and class VIIIC as the control class. The research instrument used was a multiple-choice test with four alternative answers. The instrument is first tested for the level of validity, reliability, power difference, and level of difficulty. The data is then analyzed using the t-test. Before hypothesis testing is carried out, the assumption is first tested, namely normality and homogeneity. Based on the results of the study, it was found that the average value of the experimental class posttest was 80.5, and the control class was 59.6. Based on the results of the analysis data obtained $t_{-}$count $=9.49$ and $t$ table $=1.68$ at a significant level. Because tcount $\geq t$ table, then $\mathrm{HO}$ is rejected and $\mathrm{HI}$ is accepted, which means that there are differences in Biology science learning outcomes of students between the use of jigsaw cooperative learning models assisted by student worksheets with direct learning models. Besides, it can also be concluded that the jigsaw cooperative learning model assisted by student worksheets (LKS) has a positive effect on the Biology science learning outcomes of class VIII North LengorRahong Middle School 2018/2019 academic year.

Keywords: Cooperative learning, Jigsaw, Science learning outcomes.

\section{PENDAHULUAN}

Pembaharuan sisitem pendidikan di Indonesia hampir terjadi setiap tahun dengan tujan agar mampu menghasilkan manusia Indonesia yang beradab, berdaya saing, dan berkarakter mulia walaupun diguncang akibat perkembangan zaman. Pendidikan merupakan proses membangun manusia dalam mengembangkan dirinya agar dapat menghadapi segala perubahan dan permasalahan yang terjadi dilingkungan sekitar. Pendidikan merupakan proses internalisasi budaya kedalam diri seseorang dan masyarakat sehingga membuatnya beradab

Pendidikan adalah suatu proses bimbingan atau pimpinan yang di dalamnya mengandung unsur-unsur seperti pendidik, anak didik, tujuan dan sebagainya (Ismail: 2008). UU No. 2 tahun 1989 menjelaskan bahwa Pendidikan sebagai usaha sadar untuk menyiapkan peserta didik melalui kegiatan bimbingan, pengajaran atau latihan bagi peranannya dimasa yang akan datang. atas disimpulkan bahwa pendidikan merupakan usaha sadar dan penuh tanggung jawab yang dilakukan oleh orang dewasa kepada anak sehingga timbul interaksi dari keduanya agar anak tersebut mencapai kedewasaan yang dicita-citakan dan berlangsung terus menerus. Pendidikan diharapkan mampu mewujudkan masyarakat yang terdidik, berakhlak mulia dan meningkatkan kesadaran masyarakat yang mampu hidup secara harmonis, toleransi, berwawasan kebangsaan yang demokratis serta berwawasan global. Setiap manusia harus mendapatkan pendidikan yang mampu menyentuh dimensi dasar manusia. Dimensi kemanusiaan itu mencakup tiga hal yang paling penting yaitu kognitif yang terpancar melalui kemampuan berpikir dan daya intelektual untuk menguasai, menggali dan mengembangkan ilmu pengetahuan dan teknologi (IPTEK), afektif yang terpancar melalui kualitas keimanan, budi pekerti, luhur, kepribadian yang unggul dan psikomotor yang terpancar melalui kemampuan mengembangkan 
keterampilan teknis, kecakapan praktis dan kompetensi kinestik.

Dengan adanya pendidikan, maka akan timbul dalam diri seseorang untuk bersaing untuk mencapai yang tebaik. Pendidikan bukan hanya sebuah kewajiban lebih dari itu pendidikan merupakan sebuah kebutuhan. Dimana manusia akan lebih berkembang dengan adanya pendidikan. Tujuan pendidikan yaitu mencerdaskan kehidupan bangsa dan membangun manusia Indonesia seutuhnya, yaitu manusia yang beriman dan bertaqwa kepada Tuhan Yang Maha Esa, berbudi pekerti luhur, memiliki ilmu pengetahuan dan keterampilan, sehat jasmani rohani, berkepribadian mantap dan mandiri serta bertanggung jawab terhadap bangsa dan masyarakat. Terlepas dari itu sebenarnya pendidikan adalah sesuatu yang luhur (UU Pasal 4 tahun 1989). Dimana suatu pendidikan tidak hanya sebatas dalam lembaga formal saja akan tetapi pendidikan juga ada dilingkungan informal. Karena pendidikan memiliki peran yang teramat penting bagi peningkatan kualitas sumber daya manusia.

Menilik hal itu, perkembangan pendidikan di indonesia belum sesuai dengan apa yang diharapkan. Rendahnya mutu pendidikan membuat indonesia menjadi negara yang tertinggal, karena belum berhasil meningkatkan kecerdasan, keterampilan serta karakter anak didik. Hal yang sama terjadi pula di Nusa Tenggara Timur terkhususnya di Kabupaten Manggarai. Terbukti dari survey pada tahun 2017, dimana persentase kelulusan sangat menurun yang disebabkan oleh kurangnya kreativitas guru dalam mendidik siswa. Dalam hal ini guru lebih mendominasi dalam kegitan pembelajaran. Sehingga pendidikan di Kabupaten Manggarai sepenuhnya belum berhasil membentuk peserta didik yang unggul dan berkualitas. Masih banyak pekerjaan rumah yang harus dilakukan untuk meningkatkan mutu pendidikan selain lembaga sekolah diperlukan kerja keras dari semua pihak baik itu pemerintah, masyarakat, maupun orangtua peserta didik. Keunggulan dan kualitas peserta didik dapat dibentuk melalui rangkaian usaha peningkatan hasil belajar dari segala aspek baik itu kognitif, afektif dan psikomotor.

Peran guru disini sangat dibutuhkan karena guru merupakan tenaga pendidik yang tugasnya yaitu mengajar dan mentransformasikan ilmu pengetahuan yang dimilikinya kepada peserta didik. Padahal tugas guru dalam pembelajaran adalah sebagai fasilitator yang bertugas menciptakan situasi yang memungkinkan terjadinya proses belajar pada diri siswa dan sebagai pengelola pembelajaran yang bertugas menciptakan kegiatan pembelajaran yang memungkinkan siswa mencapai tujuan pembelajaran yang optimal. Alasan ini memperkuat bahwa keberhasilan suatu pembelajaran disebabkan oleh faktor kemampuan guru dalam merencanakan dan melaksanakan pembelajaran. Pembelajaran efektif tidak akan muncul dengan sendirinya tetapi guru harus menciptakan pembelajaran yang memungkinkan siswa mencapai tujuan yang telah ditetapkan secara optimal.

Berdasarkan hasil observasi awal yang telah dilakukan menunjukkan bahwa proses pembelajaran khususnya matapelajaran IPA Biologi yang terjadi di SMPN Lengor-Lengor Rahong Utara, Kabupaten Manggarai, Nusa Tenggara Timur masih sangat minim, menyebabkan rendahnya hasil belajar IPA. Dimana siswa justru merasa jenuh dan bosan dalam menghadapi pembelajaran IPA. Pada saat proses pembelajaran berlangsung siswa terlihat kurang aktif dalam mengikuti pelajaran, 
ketidakaktifan siswa terlihat ketika guru mengadakan tanya jawab siswa kurang mampu menjawab pertanyaan guru dan bila guru meminta siswa untuk mengajukan pertanyaan siswa sama sekali tidak bertanya, ketika persentase dikelas siswa yang lain kurang menanggapi dengan semangat. Siswa banyak terlihat diam dan hanya menunggu instruksi dari guru, sehingga hal tersebut dapat mempengaruhi aktivitas dan hasil belajar siswa. Hal ini dikarenakan kurangnya kreatif dari seorang guru menerapkan model pembelajaran. Dimana dalam proses pembelajaran guru lebih menggunakan metode ceramah sehingga pembelajaran kurang melibatkan siswa dan komunikasi antar siswa dengan siswa atau guru dengan siswa kurang terbangun. Oleh karena itu siswa merasa tidak tertarik dengan pembelajaran IPA. Padahal seperti diketahui bahwa pembelajaran IPA merupakan suatu cara mencari tahu tentang alam secara sistematis untuk menguasai pengetahuan, fakta-fakta, konsepkonsep, prinsip-prinsip, proses penemuan, dan memiliki sikap ilmiah. Sehingga tidaklah tepat jika pembelajaran hanya dilaksanakan dengan metode ceramah akan tetapi melibatkan peserta didik secara aktif serta memberikan pengalaman langsung kepada peserta didik.

Salah satu upaya dalam meningkatkan kualitas pendidikan adalah dengan cara memperbaiki kualitas pembelajaran. Dimana pendidik harus mampu memilih serta menerapkan model pembelajaran yang sesuai dengan karakteristik materi sehingga mampu membelajarkan peserta didik dalam mengkonstruksi pemahaman mengenai konsep dalam mengembangkan daya nalar secara optimal. Salah satu model pembelajaran yang digunakan guru yaitu model pembelajaran kooperatif tipe jigsaw. Dengan menerapan model pembelajaran kooperatif tipe jigsaw dapat memberikan kesempatan kepada seluruh peserta didik untuk saling berinteraksi, terlibat aktif dan berani dalam menyampaikan pendapat atau ide-idenya. Pembelajaran kooperatif tipe Jigsaw didalamnya terdapat beberapa metode yaitu metode diskusi, tanya jawab dan penugasan. Sepadan dengan Rusman (dalam Shoimin, 2014: 90) menjelaskan model pembelajaran tipe jigsaw, siswa memiliki banyak kesempatan untuk mengemukakan pendapat dan mengolah informasi yang didapat dan dapat meningkatkan keterampilan berkomunikasi. Anggota kelompok bertanggung jawab atas keberhasilan kelompoknya dan ketuntasan bagian materi yang dipelajari dan dapat menyampaikan kepada kelompoknya. Menurut Sudrajat (2010: 5) menjelaskan bahwa tipe pembelajaran tipe jigsaw adalah pembelajaran yang dilakukan dengan berkelompok dan mampu mengajarkan materi tersebut kepada kelompok lainnya. Menurut Fathurrohman (2015: 63) menjelaskan bahwa model pembelajaran tipe jigsaw merupakan model pembelajaran dengan siswa belajar dalam kelompok kecil yang terdiri dari 4-6 orang 17 secara heterogen dan bekerja sama saling ketergantungan yang positif dan bertanggung jawab atas ketuntasan bagian materi pelajaran yang yang harus dipelajari dan menyampaikan materi tersebut kepada anggota kelompoknya yang lain. Dengan demikian siswa saling tergantung satu dengan yang lain dan harus bekerja sama secara kooperatif untuk mempelajari materi yang ditugaskan.

Melalui penelitian ini peneliti berharap dapat mencari solusi atas permasalahan yang dihadapi oleh guru 
terutama dalam meningkatkan hasil belajar IPA siswa Kelas VIII SMPN 2 Lengor, Kecamatan Rahong Utara, Kabupaten Manggarai dengan menerapkan model pembelajaran kooperatif tipe Jigsaw berbantuan Lembar Kerja Siswa (LKS).

Ilmu pengetahuan alam merupakan usaha manusia dalam memahami alam semesta melalui pengamatan yang tepat (correct) pada sasaran serta menggunakan prosedur yang benar (true) dan dijelaskan dengan penalaran yang sahih (valid) sehingga dihasilkan kesimpulan yang betul (truth) (Sutrisno, Leo, dkk: 2007). IPA merupakan cabang ilmu pengetahuan yang mempelajari tentang fenomenafenomena alam yang disusun melalui tahapan-tahapan metodeilmiah yang bersifat khas-khusus yaitu penyusunan hipotesis, melakukan observasi, penyusunan teori, pengujian hipotesis, penarikan kesimpulan dan seterusnya (Adeng, Slamet: 2010). Admin (2019) bahwa ilmu pengetahuan alam adalah pengetahuan yang sistematis dan berlaku secara umum (universal) yang membahas tentang sekumpulan data mengenai gejala alam yang dihasilkan berdasarkan hasil observasi, eksperimen, penyimpulan, dan penyusunan teori

Dari beberapa pendapat di atas dapat disimpulkan bahwa ilmu pengetahuan alam merupakan ilmu yang mempelajari keadaan dan kejadian alam secara sistematis melalui kegiatan pengamatan, dan percobaan untuk mengetahui fakta, konsep, proses penemuan dan sikap ilmiah.

Hasil belajar merupakan sejumlah pengalaman yang diperoleh siswa yang mencakup ranah kognitif, afektif maupun psikomotor (Rusman: 2012). Disimpulkan bahwa hasil belajar merupakan hal yang dicapai setelah individu yang bersangkutan menjalani proses belajar terhadap pengetahuan tertentu yang dinyatakan dengan nilai atau skor dimana hasil belajar berfungsi sebagai alat ukur bagi pencapaian tujuan suatu mata pelajaran atau bidang studi

Pembelajaran

kooperatif merupakan salah satu model pembelajaran kelompok yang memiliki aturan-aturan tertentu (Wena: 2008). Pembelajaran kooperatif merupakan suatu sistem yang didalamnya terdapat elemen-elemen yang saling terkait, yakni saling ketergantungan positif, interaksi tatap muka, akuntabilitas individual dan keterampilan untuk menjamin hubungan antar pribadi atau keterampilan sosial (Enjah: 2010). Pembelajaran kooperatif adalah model pembelajaran yang dirancang untuk membelajarkan kecakapan akademik sekaligus keterampilan sosial termasuk interpersonal skill (Riyanto: 2010). Menurut Slavin 20009: 8 (dalam Nurfitriyanti: 2017) bahwa dalam model pembelajaran kooperatif, para peserta didik akan duduk bersama dalam kelompok yang beranggotaan empat orang untuk menguasai materi yang disampaikan pendidik.yang kelompok yang mempunyai latar belakang kemampuan akademik, jenis kelamin, rasa tau suku yang berbeda (heterogen). Sistem dilakukan terhadap kelompok. Setiap kelompok akan memperoleh penghargaan (reward), jika kelompok mampu menunjukkan prestasi yang dipersyaratkan, sehingga setiap anggota kelompok akan mempunyai ketergantungan positif.

Dengan demikian pembelajaran kooperatif bergantung pada efektvitas kelompok-kelompok kooperatif dengan berhati-hati agar semua anggotanya dapat bekerja sama untuk memaksimalkan pembelajarannya sendiri dan pembelajaran teman satu kelompoknya. Dengan model 
pembelajaran ini, dapat menciptakan suasana ruang kelas yang terbuka (inklusif).

Model pembelajaran kooperatif tipe Jigsaw adalah suatu tipe pembelajaran kooperatifyang terdiri dari beberapa anggota dalam satu kelompok yang bertanggung jawab atas penguasaan bagian materi belajar dan mampu mengajarkan materi tersebut kepada anggota lain dalam kelompoknya (Huda, Miftahul: 2011). Sepadan dengan Arends (Dewi: 2013) bahwa pembelajaran kooperatif yang terdiri dari beberapa anggota dalam satu kelompok yang bertanggung jawab atas penguasaan bagian materi belajar dan mampu mengajarkan materi tersebut kepada anggota lain dalam kelompoknya. Hal ini berarti masingmasing peserta didik dalam kelompoknya dapat menguasai materi yang akan diajarkan kembali kepada teman satu kelompoknya. Dengan mengajarkan kembali maka peserta didik akan lebih kuat pemahamannya. Tujuan pembelajaran kooperatif tipe jigsaw menurut Anam (2000: 3) adalah sebagai berikut: 1) Menyajikan model alternatif disamping ceramah dan membaca, 2) Mengkaji kebergantungan positif dalam menyampaikan dan menerima informasi diantara anggota kelompok untuk mendorong kedewasaan berfikir, dan 3) Menyediakan kesempatan berlatih bicara dan mendengarkan untuk kognisi peserta didik dalam menyampaikan informasi. Selanjutnya, langkahlangkah teknik jigsaw menurut Anam (2000: 3) adalah sebagai berikut: 1) Tahap Kooperatif, pada tahap ini peserta didik ditempatkan dalam kelompok kecil dengan beranggotakan 5 peserta didik atau lebih.Kelompok ini disebut kelompok kooperatif dan menerima sebagian informasi atau bacaan dari satu paket informasi yang segera dibahas atau dipecahkan dalam kelompok kooperatif tersebut, 2) Tahap Ahli, sebagai anggota yang mendapat tugas tertentu peserta didik mendapat tugas yang sama melakukan hal-hal sebagai berikut: a) belajar bersama dan menjadi ahli dalam bidang informasi (bacaan) yang menjadi tugas anda, b) memecahkan cara mengajarkan informasi (isi bacaan) yang telah dikuasai kedalam kelompok kooperatif, dan c) Tahap Lima Serangkai, pada tahap ini peserta didik kelompok ahli kembali ke kelompok kooperatinya (kelompok asal). Dengan sendirinya kualitas pemecahan masalah akan lebih baik karena dikerjakan bersama oleh para ahli dibidangnya. Menurut Ajiji (2012), kelebihan metode jigsaw adalah sebagai berikut: cocok untuk semua kelas/tingkatan; bisa digunakan dalam pengajaran membaca, menulis, mendengarkan, atau berbicara; juga dapat digunakan dalam beberapa mata pelajaran; belajar dalam suasana gotong-royong mempunyai banyak kesempatan untuk mengolah informasi dan meningkatkan keterampilan berkomunikasi, sedangkan kekurangan metode jigsaw adalah sebagai berikut: membutuhkan lebih banyak waktu; dan membutuhkan pengajar yang kreatif.

Yamin, dkk. (2008) bahwa metode pembelajaran kooperative learning mempunyai manfaat-manfaat yang positif apabila diterapkan di ruang kelas. Beberapa keuntungannya antara lain: mengajarkan siswa menjadi percaya pada guru, kemampuan untuk berfikir, mencari informasi dari sumber lain dan belajar dari siswa lain; mendorong siswa untuk mengungkapkan idenya secara verbal dan membandingkan dengan ide temannya; dan membantu siswa belajar menghormati siswa yang pintar dan siswa yang lemah, juga menerima perbedaan ini. Menurut Rusman (2011: 
219) kelebihan dan kekurangan model pembelajaran tipe jigsaw adalah sebagai berikut: Kelebihan: 1) Dapat memberikan kesempatan kepada siswa untuk bekerjasama dengan siswa lain. 2) Siswa dapat menguasai pelajaran yang disampaikan. 3) Setiap anggota siswa berhak menjadi ahli dalam kelompoknya. 4) Dalam proses belajar mengajar siswa saling ketergantungan positif. 5) Setiap siswa dapat saling mengisi satu sama lain. Kekurangan: 1) Membutuhkan waktu yang lama. 2) Siswa yang pandai cenderung tidak mau disatukan dengan temannya yang kurang pandai, dan yang kurang pandai pun merasa minder apabila digabungkan dengan temannya yang pandai, walaupun lama kelamaan perasaan itu akan hilang dengan sendirinya. Sedangkan menurut Huda (2014: 151) bahwa terdapat kelebihan dan kekurangan pada model pembelajaran tipe jigsaw yaitu, sebagai berikut: Kelebihan: 1) Memberikan kesempatan yang lebih besar kepada guru dan siswa dalam memberikan dan menerima materi pelajaran yang sedang disampaikan. 2) Guru dapat memberikan seluruh kreativitas kemampuan mengajar. 3) Siswa dapat lebih komunikatif dalam menyampaikan kesulitan yang dihadapi dalam mempelajari materi. 4) Siswa dapat lebih termotivasi untuk mendukung dan menunjukkan minat terhadap apa yang dipelajari teman satu timnya. Kelemahan: 1) Memerlukan persiapan yang lebih lama. 2) Memerlukan perhatian dan pengawasan ekstra ketat dari guru. Menurut Hamdayana (2015: 89) bahwa terdapat kelebihan dan kekurangan pada model pembelajaran tipe jigsaw yaitu, sebagai berikut: Kelebihan: 1) Mempermudah pekerjaan guru dalam mengajar, karena sudah ada kelompok ahli yang bertugas menjelaskan materi kepada rekan- rekannya. 2) Pemerataan penguasaan materi dapat dicapai dalam waktu yang lebih singkat. 3) Model pembelajaran ini dapat melatih siswa untuk lebih aktif dalam berbicara dan berpendapat. Kelemahan: 1) Memerlukan persiapan yang matang. 2) Memerlukan waktu yang relatif lama. 3) Memerlukan perhatian dan pengawasan ekstra ketat dari guru. 4) Tidak efektif untuk siswa yang banyak. Berdasarkan uraian tersebut, dapat disimpulkan bahwa model pembelajaran tipe jigsaw tidak hanya memiliki kelebihan tetapi juga memiliki beberapa kelemahan. Kelebihan dari model pembelajaran tipe jigsaw yaitu siswa dapat menguasai pelajaran yang disampaikan, Model pembelajaran ini dapat melatih siswa untuk lebih aktif dalam berbicara dan berpendapat. Sedangkan kelemahan dari model pembelajaran tipe jigsaw yaitu memerlukan waktu yang relatif lama tidak efektif untuk siswa yang banyak, memerlukan perhatian dan 22 pengawasan ekstra ketat dari guru, dan memerlukan persiapan yang lebih lama.

Disimpulkan bahwa model pembelajaran kooperatif tipe jigsaw merupakan model pembelajaran yang penerapannya terdiri atas beberapa anggota dalam satu kelompok yang bertanggungjawab atas penguasaan bagian materi belajar dan mampu mengajarkan materi tersebut kepada orang laindalam kelompoknya.

Salah satu sumber belajar yang dapat dimanfaatkan dalam proses pembelajaran adalah Lembar Kerja Siswa (LKS). Lembar Kerja Siswa merupakan materi ajar yang dikemas secara terintegrasi sehingga memungkinkan siswa mempelajari materi tersebut secara mandiri (Belawati: 2006). Lembar kerja siswa (LKS) merupakan salah satu bahan ajar yang digunakan sebagai panduan untuk 
melakukan kegiatan penyelidikan atau pemecahan masalah (Trianto: 2008)

Berdasarkan pendapat di atas, dapat disimpulkan bahwa lembar kerja siswa (LKS) merupakan suatu media yang berupa lembar kegiatan yang memuat petunjuk, materi ajar dalam melaksanakan proses pemelajaran untuk menemukan suatu fakta atau konsep.

Berdasarkan masalah di atas dikemukakan rumusan masalah yaitu terdapat perbedaan hasil belajar IPA biologi antara siswa yang mengikuti model pembelajaran kooperatif tipe jigsaw berbantuan lembar kerja siswa dengan siswa yang mengikuti model pembelajaran langsung. Berdasarkan rumusan masalah di atas, penelitian ini bertujuan untuk mengetahui perbedaan hasil belajar IPA biologi siswa yang mengikuti model pembelajaran kooperatif tipe jigsaw berbantuan lembar kerja siswa dengan siswa yang mengikuti model pembelajaran langsung.

\section{METODE}

Rancangan penelitian ini mengikuti Posttest Only Control Group Design (Sugiyono, 2010). Kelompok eksperimen dalam penelitian ini dikenai perlakuan berupa penerapan pembelajaran kooperatif tipe jigsaw berbantuan lembar kerja siswa, sedangkan kelompok kontrol dikenai model pembelajaran langsung. Kedua kelompok ini dikenai pengukuran yang sama. Perbedaan hasil pengukuran yang timbul dianggap sebagai akibat dari model pembelajaran yang diterapkan. Bentuk desain penelitian dengan bagan sebagai berikut.

Tabel 1 Postest-Only Control Group

Design

\begin{tabular}{lcc}
\hline \multicolumn{1}{c}{ Kelas } & Perlakuan & Posstest \\
\hline Eksperimen & $\mathrm{X}$ & $\mathrm{O}_{1}$ \\
\hline Kontrol & & $\mathrm{O}_{2}$ \\
\hline
\end{tabular}

Ketrangan:

$\begin{array}{lll}\mathrm{X} & : & \begin{array}{l}\text { Model Pembelajaran } \\ \text { Kooperatif tipe jigsaw } \\ \text { berbantuan LKS }\end{array} \\ & \\ \mathrm{O}_{1}: & \text { Postest kelas Eksperimen } \\ \mathrm{O}_{1}: & \text { Posttest kelas control }\end{array}$

Arikunto

(2010:173)

mengatakan bahwa populasi adalah keseluruhan subyek penelitian. Sepadan dengan pendapat, Sugyiono (2010:117) mengatakan bahwa populasi adalah wilayah generalisasi yang terdiri atas subjek atau objek yang mempunyai kualitas dan karakteristik tertentu yang ditetapkan oleh peneliti untuk dipelajari dan kemudian ditarik kesimpulannya. Populasi dalam penelitian ini adalah seluru siswa kelas VIII SMP N LengorRahong Utara. Total populasi sebanyak 120 siswa. Sampel dalam penelitian ini berjumlah 47 siswa.

Tabel 2. Sampel Penelitian

\begin{tabular}{ccc}
\hline Kelas & Jlh & Keterangan \\
\hline VIIIA & 24 & Kls Eks \\
\hline VIIIC & 23 & Kls Kon \\
\hline
\end{tabular}

Teknik penentuan sampel dalam penelitian ini menggunakan teknik Probability Sampling, dengan kategori teknik penyampelan Cluster Sampling. Dengan demikian, peneliti secara langsung dapat menggunakan kelas yang sudah terbentuk di sekolah tersebut untuk dijadikan sampel penelitian. Dalam penelitian ini, instrumen digunakan untuk mengukur sejauh mana efektifitas dari penggunaan model pembelajaran model pembelajaran kooperatif tipe jigsaw berbantuan lembar kerja siswa terhadap hasil belajar IPA Biologi. Sebelum instrumen ini diberikan kepada sampel penelitian, instrumen tersebut di uji coba terlebih dahulu pada kelompok di luar sampel. Hal ini ditujukkan untuk mengetahui kelayakan dan kualitas dari instrumen yang digunakan. 
Berikut ini merupakan teknik analisis kualitas instrumen yang dilakukan peneliti dalam mengembangkan instrumen penelitian, diantaranya:

\section{Uji Validitas}

Peneliti melakukan pengujian validitas dengan mengukur validitas konstrak (construct validity), validitas isi (content validity), dan validitas empiris (empiric validity). Uji kevalidan konstrak dilakukan untuk menguji kevalidan dari instrumen tes bentuk pilihan ganda untuk mengukur hasil belajar IPA biologi siswa.

\section{Uji Validitas Konstrak dan Isi}

Pengujian validitas konstrak dan isi dilakukan melalui judgement experts, yakni meminta pendapat kepada ahli yang memiliki keterkaitan atau kepakaran dalam bidang yang terkait dengan variabel riset.

\section{Uji Validitas Empiris}

Pengujian validitas empiris dilakukan dengan teknik perhitungan statistik, yakni analisis korelasi. Perhitungan uji validitas empiris dilakukan dengan menggunakan korelasi Product Moment dengan nilai ulangan harian IPA kelas uji coba instrumen sebagai nilai pembanding. Rumus korelasi Product Moment yang dikemukakan oleh Pearson, yaitu:

$$
r_{x y}=\frac{N \sum X Y-\left(\sum X\right)\left(\sum Y\right)}{\left\{N \sum X^{2}-\left(\sum Y\right)^{2}\right\}\left\{N \sum Y^{2}-\left(\sum Y\right)^{2}\right\}}
$$

\section{Keterangan:}

$r_{x y} \quad=$ Koefisien Korelasi Jumlah

$X \quad=$ Nilai Item

$Y \quad=$ Nilai Total

Validitas suatu tes dinyatakan dengan angka korelasi koefisien (r). Untuk menafsirkan koefisien korelasi (r) yang diperoleh, peneliti dapat menggunakan kriteria acuan validitas instrumen berikut ini.

Tabel 3. Kriteria Acuan Validitas Soal

\begin{tabular}{cc}
\hline Koefisien Korelasi & Kriteria Validitas \\
\hline $0,81-1,00$ & Sangat tinggi \\
\hline $0,61-0,80$ & Tinggi \\
\hline $0,41-0,60$ & Cukup \\
\hline $0,21-0,40$ & Rendah \\
\hline $0,00-0,21$ & Sangat Rendah \\
\hline
\end{tabular}

varians butir

Varians total $\sum \sigma_{b}^{2}-$ Jumlah

$=$ Jumlah butir pertanyaan

$=$ Koefisien reliabilitas instrument (Siregar, 2013, hlm. 56)

Untuk menafsirkan nilai koefisien reliabilitas instrumen $\left(\mathrm{r}_{11}\right)$ yang diperoleh, peneliti menggunakan kriteria nilai tingkat keandalan Cronbach's Alpha berikut ini:

Tabel 4. Nilai Tingkat Keandalan Cronbach's Alpha

\begin{tabular}{cc}
\hline $\begin{array}{c}\text { Nilai Cronbach's } \\
\text { Alpha }\end{array}$ & Tingkat keandalan \\
\hline $0.0-0.20$ & Kurang Andal \\
\hline$>0.20-0.40$ & Agak Andal \\
\hline$>0.40-0.60$ & Cukup Andal \\
\hline$>0.60-0.80$ & Andal \\
\hline$>0.80-1.00$ & Sangat Andal \\
\hline
\end{tabular}

(Sumber: Heir at al, 2010, hlm. 125)

Teknik analisis data dilakukan secara kuantitatif. Data yang diperoleh melalui instrumen penelitian, selanjutnya dianalisis berdasarkan data post-test, untuk kemudian dilakukan pengujian normalitas dan hipotesis. Data yang diperoleh kemudian diolah dengan menggunakan perhitungan dengan teknik statistik inferensial. Pengolahan data penelitian ini dilakukan secara manual, juga dibantu melalui software (Microsoft Excel 2013 dan SPSS Statistics 20.0). 


$$
r_{11}=\left[\frac{k}{k-1}\right]\left[1-\frac{\sum \sigma_{b}^{2}}{\sigma_{t}^{2}}\right]
$$

\section{HASIL DAN PEMBAHASAN}

Deskripsi data yang dilakukan dalam penelitian ini meliputi rata-rata, varians, standar deviasi, nilai maksimum, dan minimum dari data yang telah terkumpul untuk mengukur hasil belajar IPA siswa. Pada penelitian ini, statistik deskriptif di hitung dengan menggunakan aplikasi microsoft office excel. Hasil statistik deskriptif tes hasil belajar IPA siswa dapat dilihat pada Tabel berikut.

Tabel 5. Ringkasan Hasil Perhitungan Skor Hasil Belajar IPA Siswa Kelas Eksperimen dan Kelas Kontrol

\begin{tabular}{lcc}
\hline \multicolumn{1}{c}{ Datatistik } & Eks. & Kont. \\
\hline Mean $(\bar{X})$ & 80.46 & 59,60 \\
\hline $\begin{array}{l}\text { Nilai Maximum } \\
\left(X_{\text {Max }}\right)\end{array}$ & 91 & 73 \\
\hline $\begin{array}{l}\text { Nilai Minimum } \\
\left(X_{\text {Min }}\right)\end{array}$ & 69 & 47 \\
\hline Standar Deviasi $(S D)$ & 6,85 & 8,11 \\
\hline Varians $\left(S^{2}\right)$ & 47.03 & 65,88 \\
\hline Median & 82 & 60 \\
\hline Modus & 71 & 51 \\
\hline Jumlah Siswa $(\mathrm{N})$ & 24 & 23 \\
\hline
\end{tabular}

Data dari hasil perhitungan skor hasil belajar IPA siswa kelas eksperimen dan kontrol dapat juga dilihat dalam masing-masing diagram berikut ini

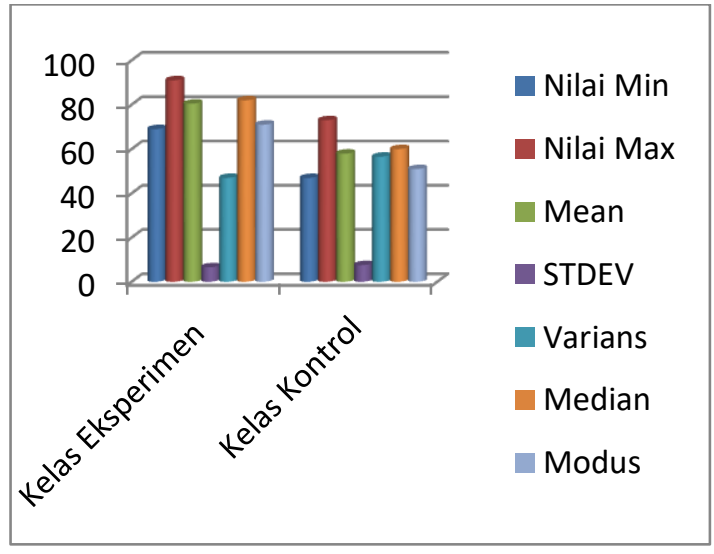

Grafik 1 Perhitungan Skor hasil belajar IPASiswa Kelas Eksperimen dan Kelas Kontrol

Setelah data yang diperoleh diolah dan didapat bahwa skor minimum pada kelas eksperimen adalah 69 dan pada kelas kontrol adalah 47, skor maximum pada kelas ekperimen adalah 91 dan pada kelas kontrol 73, mean pada kelas eksperimen adalah 80,46 dan pada kelas kontrol 59,60, median pada kelas eksperimen 82 dan pada kelas kontrol 60, modus pada kelas eksperimen 71 dan pada kelas kontrol 51. Berdasarkan hasil skor hasil belajar IPAuntuk sementara dapat dilihat bahwa skor yang diperoleh siswa pada kelas eksperimen lebih tinggi daripada skor perolehan siswa pada kelas kontrol.

\section{Deskriptif Data Posttest Kelas Eksperimen}

Hasil nilai posttest siswa kemudian diolah untuk memperoleh data hasil belajar IPA siswa. Untuk mengetahui kecenderungan klasifikasi data posteets hasil belajar IPA kelas eksperimen, maka dihitung mean ideal $\left(M_{i}\right)$ dan standar deviasi ideal (SDi). Mi $=\frac{1}{2}$ (nilai maksimum ideal+nilai minimum ideal $)=\frac{1}{2}(91+69)=80$. Standar devisiasi ideal $=\frac{1}{6}$ (nilai 
maksimum ideal - nilai minimum ideal) $=\frac{1}{6}(91-69)=3,66$. Dari hitungan tersebut, selanjutnya disusun tabel konversi kategori data hasil belajar IPA siswa kelas eksperimen menjadi 5 kategori berdasarkan pada pedomaan konversi penilaian acuan patokan (PAP) skala lima seperti Tabel 6.

Tabel. 6 Tabel Pedoman Konversi Penilaian Acuan Patokan Skala Lima (Kelas ksperimen)

\begin{tabular}{|c|c|c|c|}
\hline \multirow{2}{*}{$\begin{array}{c}\text { Rentangan } \\
\text { nilai }\end{array}$} & \multicolumn{3}{|c|}{ Jlh } \\
\hline & Kriteria & Siswa & Pers. \\
\hline$X \geq 85.5$ & $\begin{array}{l}\text { sangat } \\
\text { baik }\end{array}$ & 6 & $25 \%$ \\
\hline $81.83<X \leq 85.5$ & Baik & 7 & $29 \%$ \\
\hline $78.16<X \leq 81.83$ & Cukup & 0 & $0 \%$ \\
\hline $74.5<\mathrm{X} \leq 78.16$ & Kurang & 7 & $29 \%$ \\
\hline$X \leq 74.5$ & $\begin{array}{l}\text { sangat } \\
\text { kurang }\end{array}$ & 4 & $17 \%$ \\
\hline Jumlah & & 24 & $100 \%$ \\
\hline
\end{tabular}

Dari Tabel 6. diperoleh bahwa jumlah siswa dengan kriteria sangat baik adalah 6 orang dengan persentasenya 25\%, jumlah siswa dengan kriteria baik berjumlah 7 orang dengan persentase 29\%, jumlah siswa dengan kriteria cukup adalah 0 orang dengan persentase $0 \%$, jumlah siswa dengan kriteria kurang adalah 7 orang dengan persentasenya adalah $29 \%$, sedangkan jumlah siswa dengan kriteria sangat kurang adalah 4 orang dengan persentasenya $17 \%$.

\section{Deskriptif Data Posttest Kelas Kontrol}

Untuk mengetahui

kecenderungan klasifikasi data postest hasil belajar IPA kelas kontrol, maka dihitung mean ideal (Mi) dan standar deviasi ideal. $\mathrm{Mi}=\frac{1}{2}$ (nilai maksimum ideal + nilai minimum ideal $)=\frac{1}{2}(76+$
$47)=61,5 . \mathrm{SDi}=\frac{1}{6}$ (nilai maksimum ideal-nilai minimum ideal $)=\frac{1}{6}(76-$ $47)=4,83$. Dari hitungan tersebut, selanjutnya disusun tabel konversi kategori data hasil belajar IPA siswa kelas kontrol menjadi 5 kategori berdasarkan pada pedomaan konversi penilaian acuan patokan (PAP) skala lima seperti berikut ini.

Tabel 7. Pedoman Konversi Penilaian Acuan Patokan Skala Lima (Kelas Kontrol)

\begin{tabular}{|c|c|c|c|}
\hline Rentangan & Kriteria & Jlh & Pers. \\
\hline$X \geq 67.83$ & $\begin{array}{c}\text { sangat } \\
\text { baik }\end{array}$ & 3 & $13 \%$ \\
\hline $66.83<X \leq 67.83$ & Baik & 3 & $13 \%$ \\
\hline $59.08<X \leq 66.83$ & Cukup & 6 & $26 \%$ \\
\hline $55.16<X \leq 59.08$ & Kurang & 3 & $13 \%$ \\
\hline$X \leq 55.16$ & $\begin{array}{l}\text { sangat } \\
\text { kurang }\end{array}$ & 8 & $35 \%$ \\
\hline Jumlah & & 23 & $100 \%$ \\
\hline
\end{tabular}

Dari Tabel 7. diperoleh bahwa jumlah siswa dengan kriteria sangat baik adalah 3 orang dengan persentasenya 13\%, jumlah siswa dengan kriteria baik berjumlah 3 orang dengan persentase $13 \%$, jumlah siswa dengan kriteria cukup adalah 6 orang dengan persentase $26 \%$, jumlah siswa dengan kriteria kurang adalah 3 orang dengan persentasenya adalah $13 \%$ dan siswa dengan kriteria sangat kurang adalah 8 orang dengan persentasenya $35 \%$. Pedoman konversi penilaian acuan patokan skala lima kelas eksperimen dan kontrol dapat dilihat masing-masing dalam diagram berikut: 


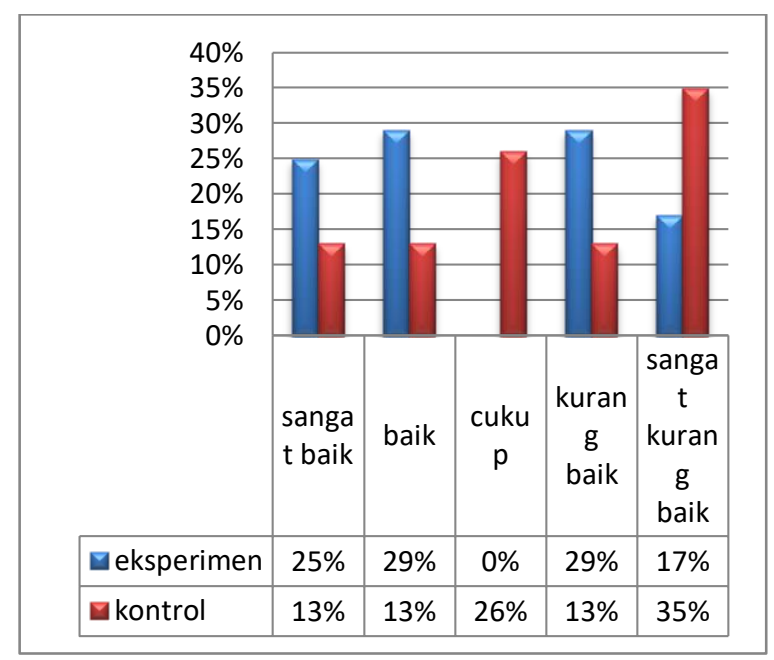

Grafik 2. Pedoman konversi penilaian acuan patokan skala lima kelas eksperimen dan kontrol.

\section{Analisis Data Hasil Penelitian}

Pengaruh model pembelajaran kooperatif tipe jigsaw bebantuan LKS diketahui dengan menggunakan beberapa uji yaitu uji asumsi dan uji hipotesis. Uji asumsi sebagai uji prasyarat untuk uji hipotesis, terdiri dari dua uji yaitu uji normalitas, yang bertujuan melihat normalitas dan homogenitas data yang diperoleh. Uji hipotesis bertujuan untuk membuktikan bahwa hipotesis peneliti diterima atau tidak.

\section{Uji Asumsi}

\section{Uji Normalitas}

Uji normalitas pada penelitian ini dilaksanakan untuk mengetahui data dari kelas eksperimen dan kelas kontrol berdistribusi normal atau tidak. Uji normalitas yang dibantu menggunakan Microsoft Excel. Hasil uji normalitas data dengan bantuan Microsoft Excell dapat dilihat pada tabel dibawah ini.
Tabel 8. Tabel Hasil Uji Normalitas Data Kelas Eksperimen dan kelas kontrol

\begin{tabular}{lcc}
\hline Deskripsi & $\begin{array}{c}\text { Kelas } \\
\text { Eksperimen }\end{array}$ & $\begin{array}{c}\text { Kelas } \\
\text { Kontrol }\end{array}$ \\
\hline Rata-rata & 80,46 & 59,60 \\
\hline $\begin{array}{l}\text { Standar } \\
\text { Deviasi }\end{array}$ & 6,85 & 8,11 \\
\hline $\begin{array}{l}\left.\chi^{2}\right) \\
\text { hitung }\end{array}$ & 1,7 & 3,57 \\
\hline$\left(\chi^{2}\right)$ tabel $=5,99$ & \\
\hline
\end{tabular}

Dari data yang terdapat pada tabel di atas didapat bahwa rata-rata pada kelas eksperimen adalah 80,46 dengan standar deviasi sebesar 6,85 dan nilai $\left(\chi^{2}\right)$ tabel dengan derajat kebebasan $(\mathrm{dk})=$ banyaknya kelas(k)-3 dengan taraf signifikan $\alpha=5 \%$, didapat chi tabel 5,99. Dari kriteria pengujian dapat dilihat bahwa data pada kelas eksperimen berdistribusi normal.

Data pada kelas kontrol didapat rata-rata kelasnya sebesar 59,6 dengan standar deviasi sebesar 8,11. Mencari nilai $\left(\chi^{2}\right)$ tabel dengan derajat kebebasan $(\mathrm{dk})=$ banyaknya kelas (k)-3 dengan taraf signifikan $\alpha=5 \%$, didapat $\left(\chi^{2}\right)$ tabel 5,99. Dari kriteria pengujian terlihat bahwa data pada kelas kontrol berdistribusi normal.

\section{Uji Homogenitas}

Setelah diadakan uji normalitas data selanjutnya diadakan uji homogenitas varians. Uji Homogenitas dalam penelitian ini bertujuan untuk melihat bahwa data yang diambil berasal dari varians yang homogen atau tidak. Dalam uji homogenitas ini, digunakan uji Fisher dengan bantuan Microsoft Excell.

Hasil uji homogenitas varians data dengan bantuan Microsoft Excelldapat dilihat pada Tabel 4.5 berikut: 
Tabel 10. Perhitungan Nilai Signifikasi Uji Homogenitas Varians

\begin{tabular}{llllll}
\hline Kelas & Mean & $\begin{array}{l}\text { Std. } \\
\text { Dev }\end{array}$ & $\begin{array}{l}\text { Jlh } \\
\text { Sis } \\
\text { wa }\end{array}$ & $\boldsymbol{F}_{\text {hit }}$ & $\boldsymbol{F}_{\text {tab }}$ \\
\cline { 1 - 5 } Eks. & 80,4 & 6,85 & 24 & 1,3 & 2,06 \\
\hline Kont. & 59,60 & 8,11 & 23 & 9 &
\end{tabular}

Dari tabel 10. di atas didapat bahwa rata-rata untuk kelas eksperimen adalah 80,4 dan untuk kelas kontrol 59,60. Standar deviasi masing-masing kelas sebesar 6,85 dan 8,11 dengan jumlah siswa 24 dan 23 orang. Dari data yang diperoleh dapat dilihat bahwa $F_{\text {hitung }}<F_{\text {tabel }}$ yang berarti data tersebut homogen.

\section{Uji Hipotesis}

Setelah dilakukan uji normalitas dan datanya berdistribusi normal serta uji homogenitas dimana variansnya homogen. Selanjutnya diadakan uji yang terakhir yaitu uji hipotesis. Sehingga memenuhi persyaratan pengujian hipotesis dengan menggunakan uji $t$ dengan rumus Separated Varian. Hipotesis penelitian yang digunakan untuk melihat hasil belajar IPA siswa adalah sebagai berikut.

$\mathrm{H}_{0}=$ Rata-rata hasil belajar IPA siswa pada kelas eksperimen lebih rendah atau sama dengan hasil belajar IPA siswa pada kelas kontrol.

$\mathrm{H}_{1}=$ Rata-rata hasil belajar IPA siswa pada kelas eksperimen lebih tinggi daripada hasil belajar IPAsiswa pada kelas kontrol.

$$
\begin{aligned}
& \mathrm{H}_{0}: \mu_{1} \leq \mu_{2} \\
& \mathrm{H}_{1}: \mu_{1}>\mu_{2}
\end{aligned}
$$

Keterangan :

$\mu_{1}$ : Rata-rata hasil belajar IPAsiswa

yang diajar dengan menerapkan model pembelajaran kooperatif tipe jigsaw berbantuan LKS

$\mu_{2}$ : Rata-rata hasil belajar IPAsiswa yang diajar dengan menerapkan pembelajaran langsung

Perhitungan uji-t dengan menggunakan separated varian dan menentukan nilai dari $t_{\text {hitung }}$ dengan rumus sebagai berikut:

$$
t=\frac{\bar{X}_{1}-\bar{X}_{2}}{\sqrt{s_{1}^{2} / n_{1}+s_{2}^{2} / n_{1}}}
$$

Hasil perhitungan uji-t untuk tes hasil belajar IPA siswa disajikan pada Tabel berikut.

\begin{tabular}{|c|c|c|c|c|}
\hline Kelas & $\mathbf{N}$ & $\mathbf{t}_{\text {hit }}$ & $\mathbf{t}_{\mathrm{tab}}$ & Kesimpulan \\
\hline Eks & 24 & & & ${\text { Menolak } \mathrm{H}_{0}}$ \\
\hline Kon & 23 & 9,49 & 1,68 & $\begin{array}{c}\text { dan } \\
\text { Menerima } \\
\mathrm{H}_{1}\end{array}$ \\
\hline
\end{tabular}

Tabel 11. Hasil Uji-t Data Kelas Eksperimen dan Kontrol

Hasil perhitungan data pada tabel di atas menunjukan bahwa $t_{\text {hitung }}=$ 9,49 dan $t_{\text {tabel }}=1.68$ pada taraf signifikan $\alpha=0,05$. Dari hasil didapat bahwa $t_{\text {hitung }}>t_{\text {tabel }}$, maka $\mathrm{H}_{0}$ ditolak dan $\mathrm{H}_{1}$ diterima. Hal ini berarti bahwa nilai rerata hasil belajar IPA siswa kelas eksperimen lebih tinggi daripada nilai rerata hasil belajar IPA siswa kelas kontrol. Dapat disimpulkan bahwa hasil belajar IPA siswa yang diajarkan model pembelajaran kooperatif tipe jigsaw berbatuan LKS lebih tinggi di bandingkan dengan hasil belajar IPA siswa yang diajarkan dengan pendekatan pembelajaran langsung.

Temuan ini diperkuat dengan hasil penelitian yang dilakukan oleh Siti 
Arifah (2014) dengan judul Penerapan Model Pembelajaran Cooperative Tipe Jigsaw dalam Matapelajaran IPA untuk Meningkatkan Hasil Belajar Siswa Pada Kelas V SDN Kutisari II Surabaya. Hasil penelitian menunjukkan bahwa persentase aktivitas guru mengalami peningkatan sebesar 23,3\% yaitu $69 \%$ pada siklus I dan 92,2\% pada siklus II. Persentase aktivitas siswa juga mengalami peningkatan sebesar $22,5 \%$ yaitu $67,5 \%$ pada siklus I dan $90 \%$ pada siklus II. Sementara itu ketuntasan belajar dengan menerapkan model pembelajaran kooperatif tipe jigsaw juga mengalami peningkatan sebesar $13,9 \%$ yaitu $70 \%$ pada siklus I dan $88,9 \%$ pada siklus II. Persentase angket respon siswa secara keseluruhan menunjukkan hasil yang baik yaitu sebesar 90\%. Dapat disimpulkan bahwa penerapan model pembelajaran kooperatif tipe jigsaw dapat meningkatkan hasil belajar siswa kelas V SDN Kutisari II Surabaya. Selain itu, Dek Ngurah Laba Laksana (2015) dengan judul penerapan model pembelajaran kontekstual berbantuan LKS dalam upaya meningkatkan pemahaman konsep IPA dan aktivitas siswa SD. Hasil penelitian menunjukkan bahwa rata-rata aktivitas belajar siswa masuk pada kategori cukup aktif. Penelitian yang dilakukan oleh Ismiyatun (2016) dengan judul Penerapan Model Pembelajaran Cooperative Tipe Jigsaw untuk Meningkatkan Hasil Belajar Siswa Pada Matapelajaran IPA di Kelas IV SD Inpres Ambesia Kecamatan Tomini. Hasil penelitian menunjukkan pada siklus I diperoleh ketuntasan belajar klasikal sebesar 33,3\% dan daya serap klasikal 44,9\%. Selain itu, hasil penelitian yang dilakukan oleh Suci Kemalasari (2018) dengan judul Pengaruh Model Pembelajaran Tipe Jigsaw Dengan Menggunakan Media
Gambar Terhadap Hasil Belajar Ips Siswa Kelas V SD Negeri 3 Metro Pusat. Hasil penelitiannya menunjukkan bahwa terdapat pengaruh yang signifikan pada model pembelajaran tipe jigsaw dengan menggunakan media gambar terhadap hasil belajar dengan pengaruh 0,7 kriteria sedang. Hasil Uji-t diperoleh data thitung sebesar 2,76 sedangkan ttabel sebesar 1,677, perbandingan tersebut menunjukkan $(2,76>1,677)$ berarti Ha diterima.

Dari hasil penelitian di atas memiliki beberapa perbedaan dengan penelitian yang peneliti laksanakan diantaranya perbedaan yang terletak pada matapelajaran, karakteristik siswa dan tempat penelitian.

\section{KESIMPULAN}

Dari keseluruhan proses dan hasil penelitian serta pembahasan terdapat kesimpulan yang diperoleh bahwa pembelajaran yang menggunakan model pembelajaran kooperatif tipe jigsaw berbantuan LKS lebih berpengaruh signifikan dibandingkan dengan pembelajaran yang menggunakan model pembelajaran langsung. Hal ini juga menguatkan hipotesis yang ada bahwa hasil belajar IPA siswa yang menggunakan model pembelajaran kooperatif tipe jigsaw berbantuan LKS lebih tinggi dibandingkan dengan hasil belajar IPA siswa yang menggunakan pembelajaran langsung.

\section{Implikasi}

Hasil pengujian hipotesis yang diperoleh dalam penelitian ini memberikan kesimpulan yang menunjukkan bahwa hasil belajar IPA siswa yang diajarkan dengan menggunakan model pembelajaran kooperatif tipe jigsaw berbantuan LKS lebih tinggi daripada hasil belajar IPA siswa yang diajarkan dengan 
menggunakan pembelajaran langsung. Hal ini memberikan implikasi bahwa model pembelajaran kooperatif tipe jigsaw berbantuan LKS lebih baik digunakan dalam meningkatkan hasil belajar IPA siswa jika dibandingkan dengan pembelajaran langsung. Oleh karena itu, model pembelajaran kooperatif tipe jigsaw berbantuan LKS perlu digunakan dalam proses pembelajaran IPA, karena dalam proses pembelajaran yang menerapkan model pembelajaran kooperatif tipe jigsaw berbantuan LKS, siswa mampu memecahkan dan menyelesaikan masalah yang diberikan melalui kegiatan diskusi dengan memperhatikan konsep-konsep IPA serta mandiri dan tanggung jawab dalam menyelesaikan tugas tersebut sehingga berdampak pada meningkatnya hasil belajar IPA siswa.

\section{Saran}

Berdasarkan uraian pembahasan dan hasil penelitian, kesimpulan, dan implikasi, maka peneliti mengajukan beberapa saran sebagai berikut:

\section{Bagi Kepala Sekolah}

Kepala sekolah diharapkan memberikan rekomendasi kepada guru IPA, agar dalam proses belajar mengajar IPA guru sebaiknya lebih jeli memilih model pembelajaran yang tepat demi perbaikan dan meningkatkan kualitas dan kuantitas proses belajar mengajar IPA khususnya biologi di masa yang akan datang, salah satunya dengan menggunakan model pembelajaran kooperatif tipe jigsaw berbantuan LKS.

\section{Bagi Guru IPA}

Seorang guru IPA hendaknya selektif dan lebih bertindak kreatif dan inovatif dalam memilih dan menggunakan model-model pembelajaran agar dapat meningkatkan hasil belajar IPA siswa, salah satunya dengan menerapkan model pembelajaran kooperatif tipe jigsaw berbantuan LKS.

\section{Bagi Peserta Didik}

Peserta didik hendaknya harus mampu untuk berusaha dalam berpartisipasi aktif dalam proses pembelajaran seperti berani mengemukakan pendapat atau gagasan, mengajukan pertanyaan maupun menjawab pertanyaan. Selain itu siswa diharapkan untuk meningkatkan kualitas belajar, dan kasil belajar IPA dengan menggunakan pendekatan model pembelajaran kooperatif tipe jigsaw berbantuan LKS.

Bagi lembaga yang terkait

Dalam proses pembelajaran di kelas model pembelajaran kooperatif tipe jigsaw berbantuan LKS masih jarang diterapkan,sebaiknya lembaga yang terkait memberikan pembinaan atau sosialisasi bagi para guru maupun calon guru denggan harapan mampu meningkatkan hasil belajar IPA siswa.

Peneliti yang akan Datang

Semoga hasil penelitian ini mampu berguna sebagai sumber rujukan bagi peneliti yang akan datang, dan mampu mengembangkan hasil penelitian ini dalam lingkup yang lebih luas, sehingga dapat menambah wawasan untuk meningkatkan kualitas pembelajaran IPA.

\section{DAFTAR PUSTAKA}

Admin. 2019. Pembelajaran pengetahuan

Alam.https://lenterakecil.com/pen gertian-ilmu-pengetahuan-alam/

Adeng, Slamet, dkk. 2010. Bahan Ajar Cetak Praktikum IPA. Jakarta: Direktorat 
Ajiji, A. 2012. Kelebihan dan Kekurangan Metode Jigsaw. Tesedia pada: http: //tasklecture.blogspot.com/2012/0 9/kelebihan-dan-kekuranganmetode-jigsaw.html

Anam, K. 2000. Implementasi Cooperatif Learning Adaptasi Model Jigsaw dan Field Study. Jakarta: Dirjen Dinasmen

Arifah, Siti. 2014. Penerapan Model Pembelajaran Cooperative Tipe Jigsaw dalam Matapelajaran IPA untuk Meningkatkan Hasil Belajar Siswa pada Kelas V SDN Kutisari II Surabaya. Jurnal Penelitian Pendidikan Guru SD, Volume 2,Nomor 2 Tahun 2014 (Jurnal). http://ejournal.unesa.ac.id/../1064 $\underline{6 \text { diakses } 13 \text { Juni } 2019}$

Arifin, Zainal. 2013. Evaluasi Pembelajaran:Prinsip Teknik Prosedur. Bandungr: PT Remaja Rosdakarya.

Arikunto, S. 2010. Dasar-Dasar Evaluasi Pendidikan. Jakarta: Bumi Aksara

Belawati.2006. Pengembangan Bahan Ajar. Jakarta:Universitas Terbuka.

Dewi, A. K. 2013. Pembelajaran Kooperatif Tipe Jigsaw. Tesedia pada: https: //ayukusumadewi.wordpress.com/ 2013/02/08/pembelajarankooperatif-tipejigsaw/

Direktorat Jendral Pendidikan Dasar Kementerian Pendidikan Nasional.2011. Pendidikan karakter dalam pembelajaran $P K N$. Jakarta: Kementerian Pendidikan Nasional

Enjah. 2010. Model Pembelajaran Kooperatif IPA. Jakarta:Genesindo. Sumedang: PT Genesindo.

Fathurrohman, Muhammad. 2015. Model-model Pembelajaran
Inovatif. Ar-ruzz Media. Yogyakarta.

Huda, Miftahul.2011 .Cooperative Learning Yogyakarta Pelajar. http://faktorfaktoryangmempengar uhihasilbelajar.html diakses 12 Maret 2019

Hamdayana, Jumanta. 2015. Model dan Metode Pembelajaran Kreatif dan Berkarakter. Ghalia Indonesia. Bogor.

Ismail. 2008. Ilmu Pendidikan Teoritis. Jakarta:Ganeca.

Ismiyatun.2016. Penerapan Model Pembelajaran Cooperative Tipe Jigsaw untuk Meningkatan Hasil Belajar Siswa pada Matapelajaran IPA di kelas IV SD

Laksana, Dek Ngurah Laba dan Katarina. 2015. Penerapan Model Pembelajaran Kontekstual Berbantuan LKS dalam Upaya Meningkatkan Pemahaman Konsep IPA dan Aktivitas Siswa SD. Jurnal Ilmiah Pendidikan Citra Bakti, Volume 2, Nomor 1 Tahun 2015 (Jurnal) halaman 79

Nurfitriyanti. 2017. Pengaruh Model Pembelajaran Kooperatif Tipe Jigsaw Terhadap Hasil Belajar Matematika Ditinjau Dari Kecerdasan Emosional. Jurnal Formatif. Jurnal Formatif 7 (2): 153-162, 2017

Riyanto.2010. Metodologi Penelitian. Surabaya: SIC

Rusman. 2012. Belajar dan Pembelajaran Berbasis Komputer. Bandung: Alfabeta.

Rusman. 2010 . Model-Model Pembelajaran. Jakarta. PT Raja Grafindo Persada.

Sugiyono. 2010. Metode Penelitian Pendidikan. Pendekatan Kuantitatif, Kualitatif, dan $R \& D$.Bandung: Alfabeta.

Sutrisno, Leo, dkk. 2007. Pengembangan Pembelajaran 
IPA SD (Bahan Ajar Cetak). Jakarta: Direktorat Jendral Pendidikan Tinggi Departemen Pendidikan Nasional 2007.

Siregar,Syofian. 2013. Statistik Parametrik untuk Penelitian Kuantitatif. Jakarta: Bumi aksara

Shoimin. 2014. Model Pembelajaran Inovatif dan Kurikulum 2013. Perpustakaan Nasional Katalog. Yogyakarta.

Sudrajat. 2008. Pengertian Pendekatan, Strategi, Metode, Teknik dan Model Pembelajaran. Sinar Baru. Bandung.

Trianto. 2008. Mendesain Pembelajaran Kontekstual (Contextual Teaching and Learning) di Kelas. Jakarta: Cerdas Pustaka Publisher.

UU Sistem Pendidikan Nasional Tahun 1989 Bab II Pasal 4

Wena, Made. 2008. Strategi Pembelajaran Inovatif Kontemporer. Jakarta Timur:Bumi Aksara.

Yamin, Martinis; Ansari, Bansu (2008). Taktik Mengembangkan Kemampuan Individual Siswa. Gaung Persada Press. 